\title{
SEKOLAH TINGGI DESAIN KOMUNIKASI VISUAL DI KOTA PONTIANAK
}

\author{
Elin Kurniati ${ }^{1}$, Rudiyono ${ }^{2}$, Uray Fery Andi ${ }^{3}$ \\ ${ }^{1}$ Mahasiswa, Program Studi Arsitektur, Fakultas Teknik, Universitas Tanjungpura. \\ elinkurniati.ek@gmail.com \\ ${ }^{2}$ Program Studi Arsitektur, Fakultas Teknik, Universitas Tanjungpura. \\ ${ }^{3}$ Program Studi Arsitektur, Fakultas Teknik, Universitas Tanjungpura.
}

Naskah diajukan pada: 28 Januari 2021

Naskah revisi akhir diterima pada: 2 Februari 2021

\begin{abstract}
Abstrak
Sektor ekonomi kreatif beberapa tahun belakangan mulai berkembang pesat berkat perkembangan teknologi digital di era 4.0. Salah satu sektor ekonomi kreatif tersebut bergerak di bidang desain komunikasi visual. Hal ini terbukti dari berbagai peluang dan kebutuhan akan tenaga profesional di bidang desain serta sektor usaha lainnya. Namun, fasilitas pendidikan yang menyelenggarakan serta menghasilkan tenaga profesional di bidang desain komunikasi visual masih belum tersedia di Kota Pontianak. Kota Pontianak yang merupakan ibu kota Kalimantan Barat sekaligus pusat aktivitas penduduk Kalimantan Barat dinilai sebagai lokasi yang strategis untuk diselenggarakan fasilitas pendidikan tinggi berupa Sekolah Tinggi Desain Komunikasi Visual. Sekolah Tinggi Desain Komunikasi Visual di Kota Pontianak merupakan Lembaga Pendidikan Tinggi yang menyelenggarakan pendidikan di bidang desain dengan mempelajari segala sesuatu yang berkaitan dengan media komunikasi (terutama media komunikasi visual). Dalam program pendidikannya, sekolah tinggi ini akan menghasilkan tenaga profesional dengan prospek dunia kerja bidang desain di antaranya: desainer grafis, multimedia, komunikasi visual, desain produk, illustrator, photografer, animator, web designer di Kota Pontianak. Tahap perancangan Sekolah Tinggi menggunakan metode perancangan J.C. Jones yang diawali tahap gagasan, pengumpulan informasi/data, analisis, sintesis, evaluasi dan optimalisasi. Tahapan perancangan ini bertujuan menghasilkan Konsep Perencanaan dan Perancangan Sekolah Tinggi Desain Komunikasi Visual yang dapat menunjang pengembangan keterampilan dan kreativitas penggunanya serta menjadi salah satu upaya meningkatkan kualitas pendidikan dan sumber daya manusia di Kota Pontianak.
\end{abstract}

Kata-kata Kunci: Perancangan, Sekolah Tinggi, Desain Komunikasi Visual, Teknologi Digital, Kota Pontianak

\begin{abstract}
Over the recent years, the creative economy sectors has shown rapid growth thanks to the development of digital technology in 4.0 era. Visual Communication Design is one of those sectors mentioned above. It's proven by variant opportunities and needs of professionals in design field and similar others. However, educational facilities that organizing and producing labor in Visual Communication Design is still unavailable in Pontianak. Pontianak, Capital of West Borneo/Kalimantan which is well known as central of west kalimantan's populations' activites is considered as a strategic location to establish higher educational facilities for Visual Communication Design sector. Academy of Visual Communication Design in Pontianak is a tertiary education institution that organizes education in design field by providing studies related to media and communication. (especially Visual Communication Design). Throughout the education program, the academy will produce professional labors with prospects of the world of work in the field of design including: graphic designers, multimedia, visual communication, product design, illustrator, photographers, animators, web designers in Pontianak. The planning stage of the Academy using J.C. Jones model which consists of concept, data collecting, analyze, synthesize, evaluation and optimalization. Those stages aims to produce a concept to build Academy of Visual Communication Design that will able to help the development of skills and creativities of it learners in order to increase human resource qualities in Pontianak.
\end{abstract}

Keywords: Design, College, Visual Communication Design, Digital Technology, Pontianak City 


\section{Pendahuluan}

Perkembangan teknologi digital di era 4.0 semakin meningkat pesat dimana salah satunya memiliki pengaruh yang cukup besar pada laju pertumbuhan ekonomi Kota Pontianak khususnya di sektor informasi dan komunikasi yang mencapai $11,88 \%$, angka tertinggi dari sektor usaha lainnya (Badan Pusat Statistik Kota Pontianak, 2017). Pengaruh lain dari revolusi industri 4.0 juga mulai terlihat dari sektor ekonomi kreatif yang beberapa tahun belakangan mulai berkembang pesat berkat teknologi digital. Melalui data statistik dan hasil survei Badan Ekonomi Kreatif (2016), empat subsektor yang mengalami pertumbuhan yang sangat pesat yakni: TV dan radio, film, animasi dan video, seni pertunjukan, serta desain komunikasi visual dengan persentase pemanfaatan media internet didominasi oleh subsektor Desain Komunikasi Visual (DKV).

Desain Komunikasi Visual (DKV) merupakan istilah dari proses pengolahan media dalam menyampaikan informasi atau mengungkapkan pemikiran melalui desain yang ditampilkan secara visual berupa foto, diagram, ilustrasi, permainan warna, dan sebagainya. Penggunaan teknologi digital pada masa ini telah mengubah cara penyampaian informasi menjadi desain visual sehingga informasi yang disampaikan menjadi lebih menarik. Pengaruh dari perkembangan teknologi, khususnya komputer yang semakin canggih menyebabkan perkembangan desain komunikasi visual di Indonesia bahkan di dunia kian berkembang pesat karena kualitas teknologi yang digunakan sangat mempengaruhi kualitas suatu karya. Peningkatan kualitas desain komunikasi visual di Indonesia pun meningkatkan animo atau minat masyarakat Indonesia bahkan masyarakat Pontianak terhadap bidang desain tersebut.

Munaf (2016), selaku Kepala Badan Ekonomi Kreatif (Bekraf) mengatakan “Ke depan, keberadaan desain komunikasi visual/grafis dan desain produk akan menjadi penting dalam perkembangan industri kreatif'. Didukung oleh kebutuhan berbagai sektor usaha seperti branding, materi tampilan, desain katalog, dan lain-lain. Hal ini tentunya membuat para pelaku usaha baik di sektor Informasi dan Komunikasi maupun sektor-sektor lainnya sangat memerlukan sumber daya manusia sebagai tenaga profesional yang mahir di bidang desain visual. Tenaga profesional yang dibutuhkan tidak hanya harus mempunyai keahlian (skill) komputer dan ilustrasi tetapi juga harus mempunyai pengetahuan (knowledge) akan pengembangan konsep yang menunjang hasil desain. Pengembangan keahlian dan pengetahuan yang berkualitas tentunya tidak dapat dipisahkan dari peranan desain sebagai bidang ilmu.

Kota Pontianak sudah mulai mengenal istilah desain komunikasi visual secara garis besar. Istilah desain komunikasi visual masih cukup asing bagi orang awam, tetapi bidang ini cukup diminati oleh masyarakat Kota Pontianak. Namun, Kota Pontianak belum memiliki perguruan tinggi yang menyelenggarakan pendidikan di bidang desain komunikasi visual. Hal ini membuat banyak diantara kalangan pelajar memilih melanjutkan pendidikan di luar Kalimantan Barat agar bisa melanjutkan pendidikan pada bidang desain komunikasi visual.

Sebagai ibu kota Kalimantan Barat, Kota Pontianak merupakan sentral berbagai aktivitas penduduk Kalimantan Barat, baik dari segi pendidikan, administrasi, maupun kegiatan ekonomi. Oleh karena itu rasanya diperlukan wadah yang dapat menampung kegiatan pendidikan, ruang untuk berkarya serta ruang yang memberikan informasi dan wawasan dalam bidang desain. Berdasarkan fenomena yang ada maka diperlukan gagasan untuk penyediaan fasilitas edukasi berupa institusi pendidikan baru berupa pendidikan tinggi yang menyelenggarakan pendidikan di bidang desain komunikasi visual yang dapat menampung kegiatan pendidikan serta mampu mencetak SDM berkualitas dan kompeten dalam mendukung perkembangan zaman.

Sekolah Tinggi Desain Komunikasi Visual di Kota Pontianak merupakan Lembaga Pendidikan Tinggi yang menyelenggarakan Pendidikan di bidang desain dengan mempelajari segala sesuatu yang berkaitan dengan media komunikasi (terutama media komunikasi visual). Lembaga Pendidikan Tinggi ini diharapkan dapat menampung dan menyalurkan potensi sumber daya manusia terhadap penggunaan teknologi dan penerapan desain. Sehingga dalam program pendidikannya, sekolah tinggi 
ini dapat menunjang pengembangan keterampilan dan kreativitas penggunanya, diharapkan juga akan dapat menghasilkan tenaga kerja profesional dengan prospek dunia kerja bidang desain di antaranya: desainer grafis, multimedia, komunikasi visual, desain produk, illustrator, photografer, animator, web designer) di Kota Pontianak.

\section{Kajian Pustaka}

Menurut Saputra (2010), Desain Komunikasi Visual (DKV) atau yang biasa disebut Desain Grafis atau Grafis Komunikasi adalah cara berpikir manusia untuk menginterpretasikan informasi yang disajikan dari bentuk yang komplek sampai kebentuk sederhana, sehingga lebih mudah dipahami, diingat dan diketahui maknanya. Sedangkan menurut Ardjaka (1991), Desain komunikasi visual adalah cabang disiplin ilmu terkait media komunikasi (terutama media komunikasi visual) dan dalam media tersebut wajib memuat berbagai macam informasi yang akan disampaikan kepada masyarakat umum sebagai konsumen serta audien.

Menurut Undang-Undang Republik Indonesia Nomor 12 tahun 2012 pasal 59 tentang Pendidikan Tinggi, Sekolah Tinggi merupakan Perguruan Tinggi yang menyelenggarakan pendidikan akademik dan dapat menyelenggarakan pendidikan vokasi dalam satu rumpun Ilmu Pengetahuan dan/atau Teknologi tertentu dan jika memenuhi syarat, sekolah tinggi dapat menyelenggarakan pendidikan profesi.

Menurut Keputusan Menteri Ketenagakerjaan Republik Indonesia Nomor 301 Tahun 2016, fungsi utama dari Desain Grafis/DKV adalah merancang solusi komunikasi visual melalui program identitas, informasi dan persuasi yang sesuai tujuan yang ditetapkan dengan menggunakan media konvensional (berbasis cetak) maupun non konvensional (non cetak).

Menurut Persada (2015), Fungsi Sekolah Tinggi Desain Komunikasi Visual dalam kaitannya sebagai bangunan yang mewadahi kegiatan pendidikan desain komunikasi visual maupun wadah untuk mengapresiasi karya desain grafis sebagai karya seni dengan berbagai media yang diolah secara kreatif.

Berdasarkan Permenristekdikti No. 44 tahun 2015 tentang SN Dikti Pasal 32, perguruan tinggi harus memiliki kualitas gedung negara minimal kelas B atau setara. Gedung perguruan tinggi juga harus memenuhi persyaratan keselamatan, kesehatan, kenyamanan dan keamanan, serta memiliki prasarana instalasi listrik, penanganan limbah domestik maupun khusus yang memadai.

\section{Metode}

Metode perancangan yang digunakan pada Perancangan Sekolah Tinggi Desain Komunikasi Visual di Kota Pontianak adalah metode perancangan oleh J. C. Jones (Nuraini, 2010). Metode ini terdiri dari beberapa tahapan yang dimulai dari tahap gagasan sebagai penentu judul perancangan dilengkapi dengan berbagai informasi untuk memperkuat gagasan seperti latar belakang dan permasalahan. Tahap selanjutnya yaitu tahap pengumpulan data terkait kebutuhan perancangan dan lokasi perancangan melalui studi literatur, studi banding, aturan, norma, serta standar yang berlaku. Setelah data terkumpul dilanjutkan dengan tahap analisis, dimana pada tahap ini data yang telah diperoleh kemudian dirangkum untuk diolah agar menemukan solusi dan pemecahan permasalahan. Setelah dilakukannya tahap analisis, tahap selanjutnya adalah tahap sintesis berupa penarikan hasil kesimpulan dari analisis yang telah dilakukan sebelumnya berupa Konsep Perencanaan dan Perancangan yang akan dijadikan pedoman atau acuan dalam proses perancangan yang dipaparkan dalam bentuk sketsa dan gambar. Kemudian pada tahap selanjutnya Konsep Perencanaan dan Perancangan yang telah dihasilkan pada tahap sintesis di evaluasi, untuk mengetahui kekurangan yang perlu diperbaiki. Tahap terakhir pada metode perancangan ini yaitu optimalisasi, dimana setelah mengevaluasi kekurangan pada Konsep Perencanaan dan Perancangan sebelumnya akan dioptimalkan dalam perancangan. 


\section{Hasil dan Pembahasan}

Proses dari pembahasan terdiri dari proses pemilihan lokasi perancangan dan proses landasan konseptual berupa analisis eksternal dan internal sehingga didapatkan konsep perancangan berupa konsep gubahan bentuk, konsep struktur, konsep utilitas, serta hasil perancangan.

\section{Lokasi Perancangan}

Menurut Peraturan Pemerintah No. 19 tahun 2005 tentang Standar Nasional Pendidikan Pasal 44, lahan untuk mendirikan Sekolah Tinggi Desain Komunikasi Visual memiliki beberapa kriteria yaitu, lahan tersebut dimaksudkan untuk bangunan satuan pendidikan berupa lahan praktek, lahan untuk menunjang prasarana, dan lahan pertamanan agar satuan pendidikan tersebut menjadi lingkungan yang secara ekologis nyaman dan sehat. Adapun standar lahan satuan pendidikan dinyatakan dalam rasio luas lahan per peserta didik dengan mempertimbangkan letak lahan satuan pendidikan di dalam klaster satuan pendidikan sejenis dan sejenjang, serta letak lahan tersebut di dalam klaster satuan pendidikan yang menjadi pengumpan masukan peserta didik.

Lokasi perancangan berada di Jalan Perintis Kemerdekaan, Dalam Bugis, Kecamatan Pontianak Timur, Kota Pontianak, Kalimantan Barat. Berdasarkan peraturan Rencana Tata Ruang Wilayah Kota Pontianak Tahun 2013-2033, terdapat beberapa ketentuan tapak meliputi: Koefisien Dasar Bangunan (KDB) lokasi sebesar maksimal 70\%, Koefisien Lantai Bangunan (KLB) 2.4, KDH $40 \%$, GSB 4 meter simetris dan RMJ 6 meter dengan luas site +3.8 hektar. Lokasi perancangan memiliki infrastruktur yang memadai berupa jalan, jaringan telepon, jaringan listrik, dan penyediaan air bersih.

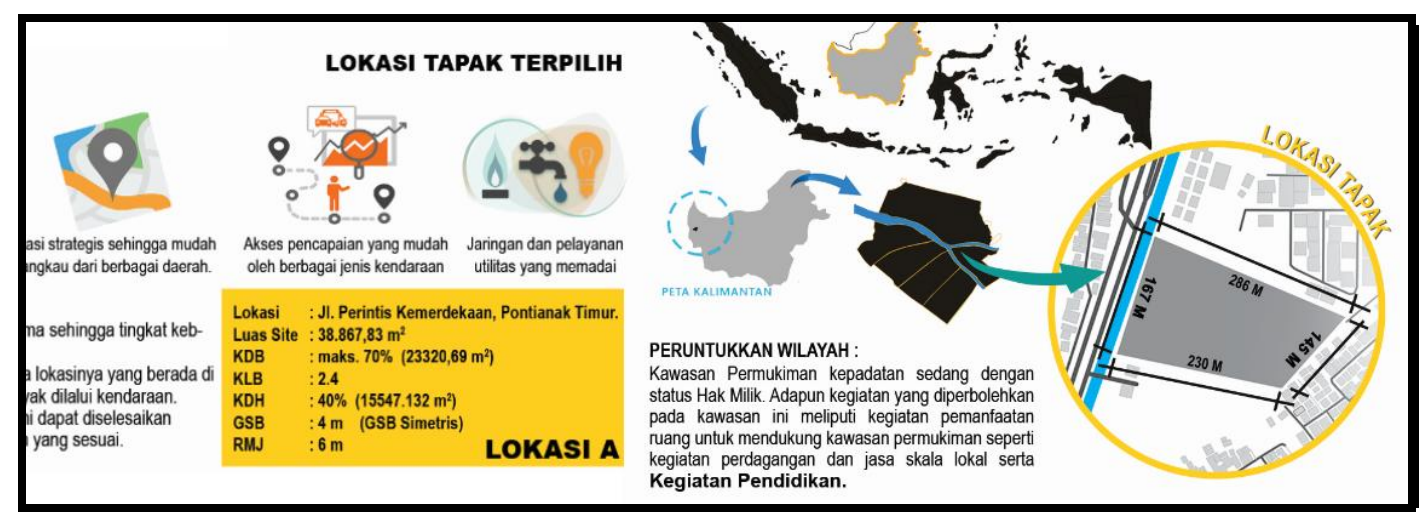

Gambar 1. Lokasi Perancangan Sekolah Tinggi Desain Komunikasi Visual di Kota Pontianak Sumber: Penulis, 2020

\section{Landasan Konseptual}

Landasan konseptual merupakan pemaparan proses analisis internal dan eksternal terhadap data-data yang telah dikumpulkan dalam menemukan solusi dan pemecahan permasalahan sehingga menghasilkan konsep Perencanaan dan Perancangan Sekolah Tinggi Desain Komunikasi Visual di Kota Pontianak. Pada analisis internal, fungsi dari Sekolah Tinggi Desain Komunikasi Visual di Kota Pontianak mewadahi tiga fungsi yaitu, fungsi utama yaitu fungsi pendidikan berupa fasilitas kemahasiswaan; fungsi pendukung terdiri dari fungsi administrasi dan informasi berupa fasilitas rektorat; serta fungsi penunjang terdiri dari fungsi kunjungan berupa fasilitas auditorium dan masjid sarana ibadah. 


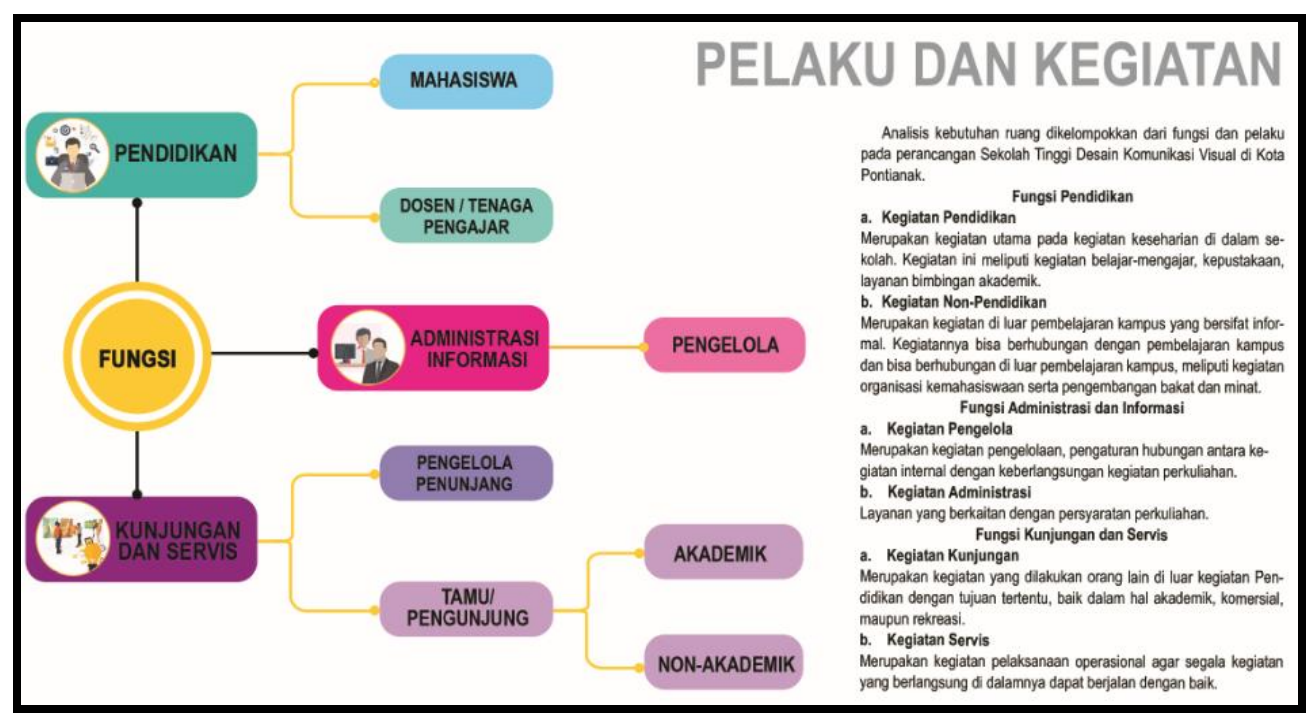

Gambar 2. Analisis Fungsi Sekolah Tinggi Desain Komunikasi Visual di Kota Pontianak Sumber: Penulis, 2020

Analisis eksternal Sekolah Tinggi Desain Komunikasi Visual di Kota Pontianak terbagi menjadi zonasi, peletakan, orientasi, sirkulasi, dan vegetasi. Berdasarkan hasil analisis zonasi, bagian depan kawasan merupakan zona publik berupa area parkir. Selain zona publik, area depan juga terdapat zona semi publik dan semi privat yang merupakan pemisah antara zona publik dan zona privat serta menjadi ikon dari kawasan. Pada bagian belakang kawasan merupakan zona privat yang membutuhkan suasana yang tenang dan kondusif serta zona servis kawasan.

Peletakan posisi seluruh massa bangunan terletak di dalam masing-masing zonasi dengan mengikuti peraturan yang berlaku untuk tidak berada di luar dari garis sempadan bangunan (GSB) dan garis sempadan samping bangunan (GSSB). Area yang berada di luar dari garis sempadan dan sempadan samping bangunan tersebut digunakan sebagai area RTNH, yaitu lahan parkir kendaraan, gerbang entrance, dan lapangan. Adapun peletakan massa bangunan utama condong ke arah selatan dengan sirkulasi angin yang baik dan jauh dari tingkat kebisingan.

Orientasi utama kawasan yaitu menghadap ke arah jalan utama dengan pertimbangan akses pencapaian yang mudah serta mudah terlihat dan menarik perhatian orang yang melalui jalan tersebut. Adapun orientasi pendukung kawasan menghadap ke arah selatan karena pada arah ini view ke dalam kawasan tidak terhalang oleh bangunan apapun sehingga bisa terlihat dari arah kejauhan. Pada view yang menghadap ke permukiman warga akan diberikan pembatas berupa pagar maupun vegetasi agar tidak mengganggu kegiatan sekitar.

Sirkulasi utama berupa akses masuk dan keluar kawasan dari arah jalan utama dengan akses utama masuk dan keluar kawasan berada di tengah serta diberikan satu akses keluar tambahan yang diperuntukkan bagi mahasiswa, dosen, dan pengelola. Adapun sirkulasi pengunjung berada pada area depan sedangkan sirkukasi mahasiswa, dosen, dan pengelola berada pada area belakang.

Vegetasi yang terdapat di dalam kawasan sepenuhnya ditebang. Pada area depan kawasan diberi vegetasi buffer sebagai pereduksi kebisingan dan polusi serta diberi vegetasi hias yang menjadi daya tarik pada area publik, sedangkan pada area tengah kawasan diberi vegetasi peneduh dan penghias agar menciptakan suasana nyaman pada area pejalan kaki. Adapun disepanjang jalur sirkulasi diberi pohon pengarah yang menunjukan jalur sirkulasi kawasan. 


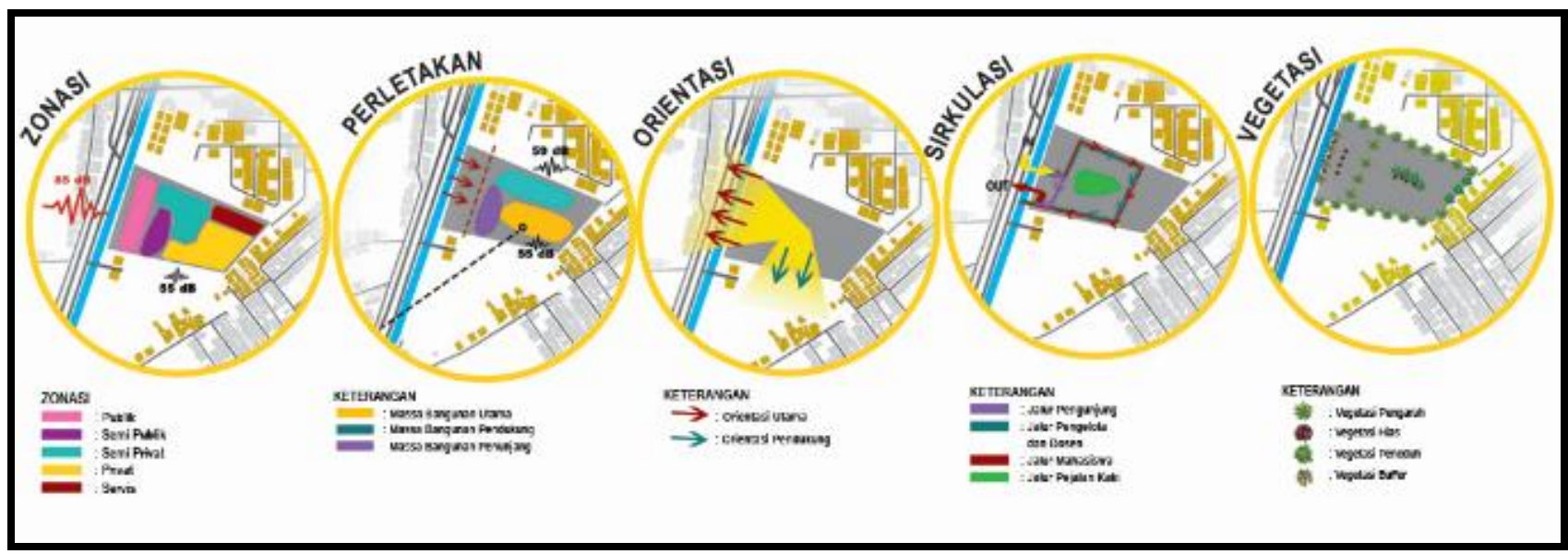

Gambar 3. Analisis Eksternal Sekolah Tinggi Desain Komunikasi Visual di Kota Pontianak Sumber: Penulis, 2020

\section{Konsep Gubahan Bentuk}

Gubahan bentuk merupakan tahap akhir dari hasil analisis bentuk dan analisis eksternal yang menghasilkan bentukan dasar bangunan serta peletakan tata massa bangunan pada kawasan. Bentukan dasar masing-masing gedung berbentuk persegi karena lebih menekankan pada aspek fungsional sehingga penyusunan ruang lebih efektif dan efisien terutama bagi bangunan pendidikan.

Berlandaskan dari ide perancangan, penerapan konsep playful and fun melalui permainan warna dan bentuk fasad bangunan. Fasad pada massa bangunan di dalam kawasan ini dibuat dengan kesan terbuka dengan selasar-selasar yang menampilkan kolom dan balok yang menopang bangunan sehingga menampilkan kesan bangunan yang kokoh.

Permainan fasad dengan permainan sudut kemiringan dinding dikombinasikan dengan bukaan yang besar bertujuan agar mengurangi intensitas panas matahari sore yang masuk ke dalam bangunan, secara akustika permainan fasad pada dinding juga dapat menyebarkan suara dengan baik. Penggunaan sun shading juga diterapkan pada massa bangunan di kawasan ini, yaitu pada Gedung Rektorat dan Gedung Auditorium. Hal ini dikarenakan kedua massa ini berada pada area depan yang terkena paparan matahari sore sehingga diberikan sun shading agar tidak mempengaruhi fungsi di dalam gedung. Selain sebagai selimut bangunan, sun shading juga menambah estetika pada bangunan dan menciptakan kesan simetri pada kedua massa ini.

Secara kontekstual, pertimbangan lain juga diterapkan pada bentuk atap yang merupakan gabungan bentuk atap perisai dan atap dak. Hal ini dikarenakan iklim di Kota Pontianak yang memiliki curah hujan yang tinggi. Adapun material penutup atap yang digunakan yaitu atap bitumen. 


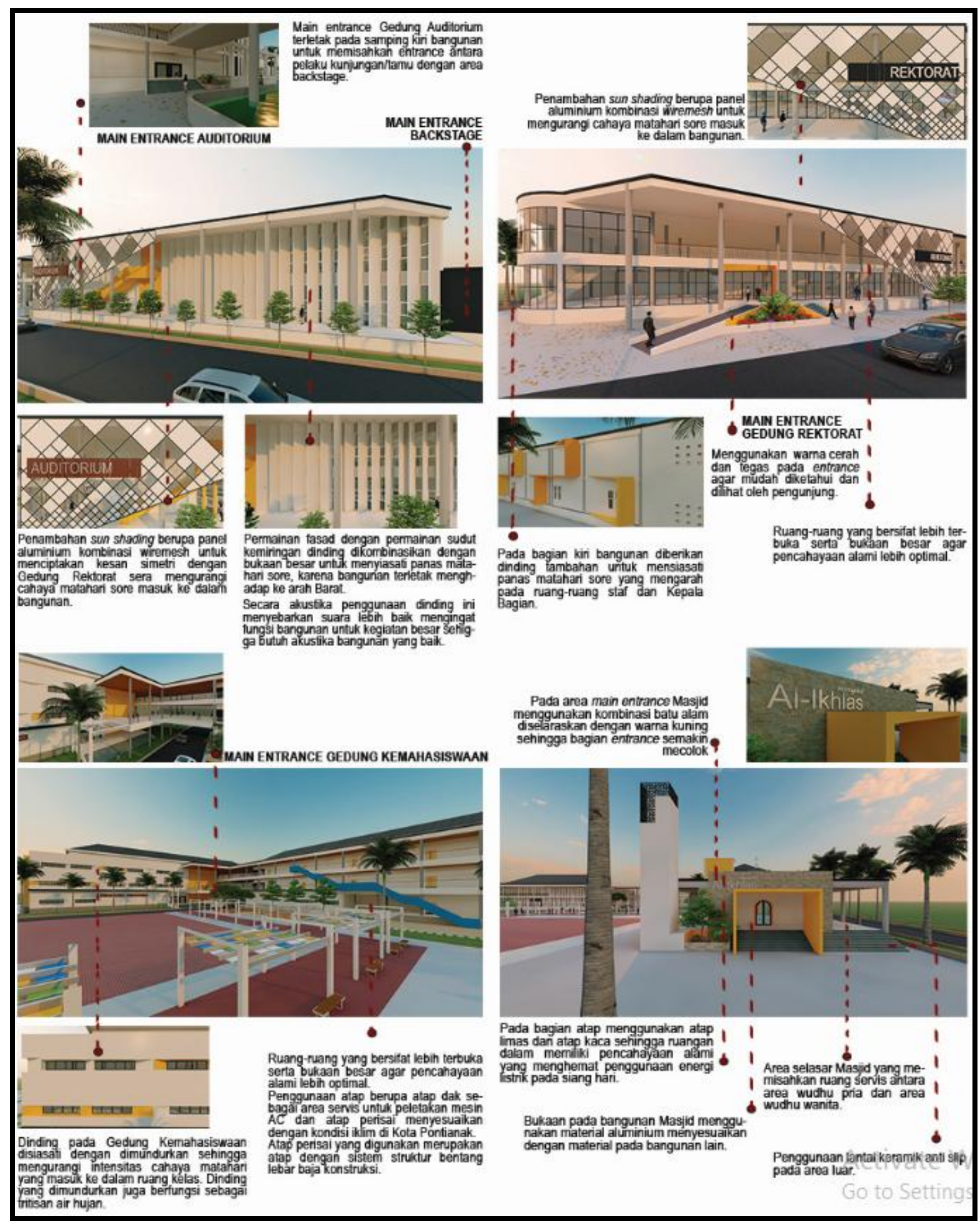

Gambar 4. Konsep Gubahan Bentuk

Sumber: Penulis, 2020

\section{Konsep Struktur}

Analisis konsep struktur Sekolah Tinggi Desain Komunikasi Visual terdiri dari 4 massa bangunan dengan kesamaan modulasi bangunan. Modulasi bangunan berdasarkan kelipatan angka besaran ruang yang tipikal, yaitu 6 × 6 m. Adapun pada Gedung Kemahasiwaan terdapat modulasi 8 $\mathrm{x} 12 \mathrm{~m}$ khusus untuk ruang kuliah teori. 
Kawasan Sekolah Tinggi Desain Komunikasi Visual di Kota Pontianak terdiri dari bangunan dengan level lantai berbeda, yaitu tiga lantai, dua lantai, dan satu lantai. Sistem struktur bawah (sub structure) pada masing-masing gedung menggunakan pondasi titik dengan jenis pondasi pelat dan mendapat tambahan penguatan dari mini pile. Jenis mini pile yang digunakan adalah mini pile berbahan beton bertulang.

Sistem struktur atas (upper structure) pada bangunan menggunakan sistem rangka beton bertulang mengikuti modul bangunan. Berdasarkan hasil analisis, pada bentang $8 \times 12 \mathrm{~m}$ ukuran balok induk yaitu yaitu $0,25 \times 0,60 \mathrm{~m}$ dan kolom dengan diameter $0,40 \mathrm{~m}$, pada bentang $6 \times 6 \mathrm{~m}$, ukuran balok induk yaitu 0,25 x $0,50 \mathrm{~m}$ dan kolom dengan diameter $0,40 \mathrm{~m}$.

Rangka atap bangunan menggunakan sistem truss dengan pertimbangan dari bentuk atap. Bahan rangka atap truss ini yaitu baja struktural untuk bentangan sedang. Perancangan ini memilih dua jenis bentuk baja IWF untuk kuda-kuda dan profil $\mathrm{C}$ untuk gording. Penutup atap untuk seluruh atap dalam perancangan gedung yaitu atap bitumen dengan pertimbangan atap bitumen cocok untuk atap dengan bentang yang lebar, lebih ringan dibanding jenis atap lain, dapat meredam suara serta memiliki nilai estetika.

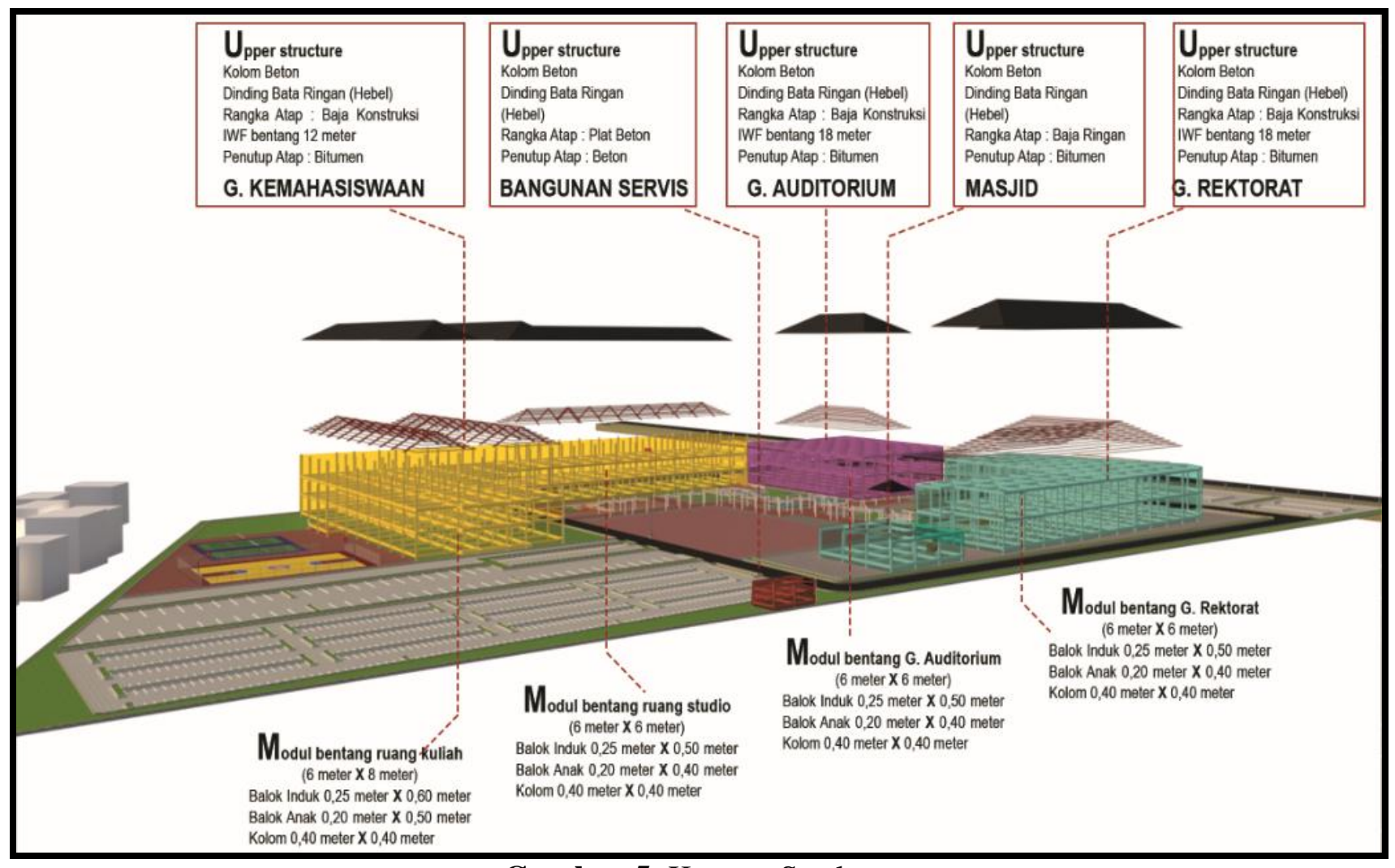

Gambar 5. Konsep Struktur

Sumber: Penulis, 2020

\section{Konsep Utilitas}

Analisis utilitas mencakup jaringan air bersih, jaringan air kotor dan drainase, jaringan listrik, jaringan informasi dan komunikasi, keamanan bangunan, jaringan jaringan tata udara, pemadam kebakaran, dan persampahan. Instalasi air bersih menggunakan sistem up feed dengan sumber air bersih yang berasal dari PAM dan air hujan yang dialirkan dengan bantuan pompa. Sistem sanitasi air kotor pada kawasan menggunakan sistem pengolahan limbah pada umumnya. Limbah lavatory dari kloset akan dialirkan ke septic tank serta limbah lavatory dari wastafel dan floor drain akan dialirkan ke perangkap sabun, adapun limbah kitchen sink dari cafeteria akan dialirkan ke grease trap. Kemudian, limbah olahan dari septic tank, perangkap sabun, dan grease trap akan dialirkan 
menuju STP (Sewage Treatment Plant) untuk diolah kembali sehingga air kotor dapat dialirkanke riol kota dan sebagian dari pengolahan ini akan difungsikan sebagai penyiraman tanaman dan flushing toilet.

Sistem jaringan listrik kawasan Sekolah Tinggi Desain Komunikasi Visual di Kota Pontianak menggunakan sumber dari PLN (Perusahaan Listrik Negara) sebagai sumber energi listrik utama dan genset sebagai sumber energi listrik cadangan. Sistem keamanan bangunan terdiri dari penggunaan CCTV pada area komunal dan sistem proteksi kebakaran. Sistem proteksi kebakaran menggunakan beberapa jenis alat, yaitu alaram, springkler, PAR, hidran bangunan, hidran kawasan dan Fire Suppression System yang diperuntukkan untuk melindungi dokumen-dokumen penting serta peralatan elektronik yang terdapat di Sekolah Tinggi Desain Komunikasi Visual di Kota Pontianak.

Sistem jaringan informasi dan komunikasi pada perancagan ini menggunakan sistem komunikasi IP-PABX yang bersumber dari Telkom, dimana pada jaringan telepon sinyal analog diubah menjadi sinyal digital yang disalurkan melalui jaringan IP. Adapun untuk sistem informasi menggunakan media speaker untuk penyampaian kepada mahasiswa secara massal dan terhubung dengan jaringan peringatan kebakaran. Pusat kontrol jaringan informasi dan komunikasi terdapat pada masing-masing gedung.

Sistem jaringan tata udara pada masing-masing gedung menggunakan sistem AC VRV yang diterapkan pada ruang-ruang yang bersifat privat dan semi privat. Adapun output indoor dari penggunaan sistem ini terdiri dari ceiling mounted cassette (round flow with sensing) yang dapat dikontrol menggunakan touch manager. Adapun sistem persampahan pada kawasan Sekolah Tinggi Desain Komunikasi Visual berupa pengumpulan sampah yang dilakukan pada waktu aktivitas kawasan relatif sepi dan ditampung dipenampungan sementara.

\section{Hasil Perancangan}

Hasil perancangan merupakan transformasi dari analisis dan konsep menuju gambar pra rancangan meliputi gambar situasi, gambar siteplan, gambar denah, gambar tampak, gambar perspektif suasana eksterior dan perspektif suasana interior.

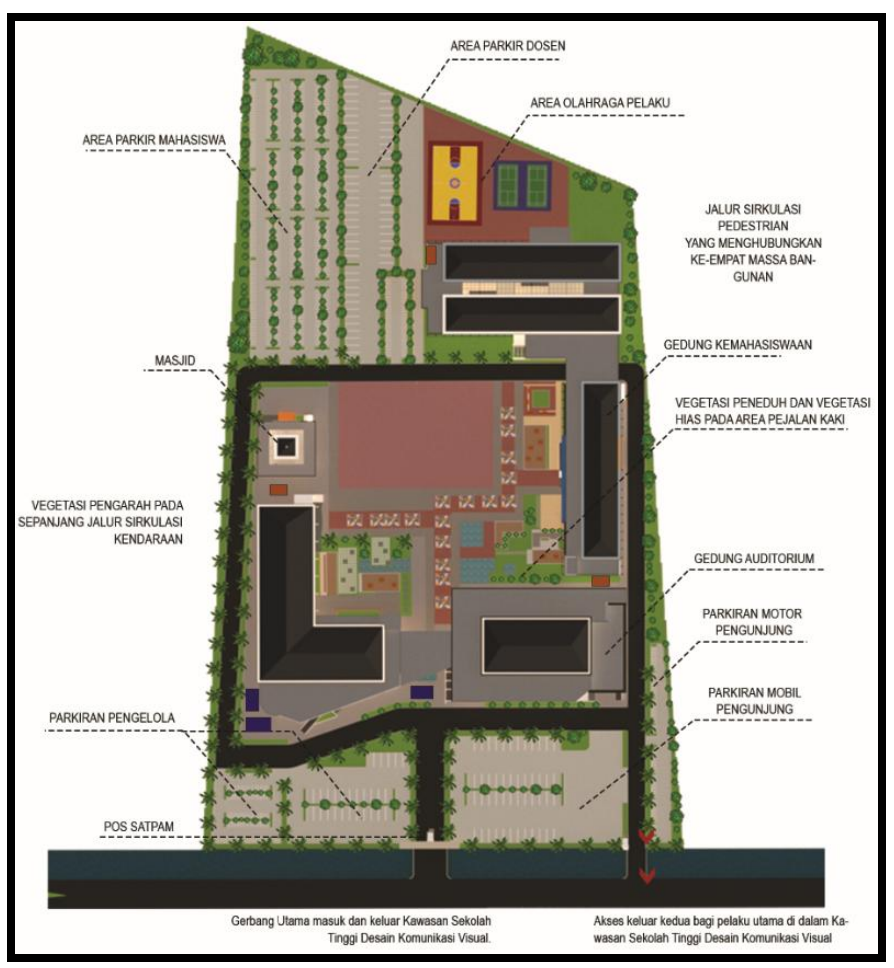

Gambar 6. Siteplan

Sumber: Penulis, 2020 
Gambar siteplan menunjukkan Sekolah Tinggi Desain Komunikasi Visual di Kota Pontianak mempunyai empat massa bangunan, yaitu Gedung Rektorat, Gedung Auditorium, Gedung Kemahasiswaan, dan Masjid. Akses pada kawasan terbagi menjadi 2 jenis berdasarkan kendaraan maupun pejalan kaki, yaitu akses publik dan privat. Akses publik berfokus pada area depan Gedung Rektorat dan Gedung Auditorium. Akses ini berperan sebagai jalur kendaraan motor, mobil, dan bus. Akses privat berfokus hanya pada pelaku utama seperti mahasiswa, dosen dan staf utama lainnya. Akses kendaraan privat ini berada pada zona terluar dari tapak agar pada area dalam tapak berfokus pada akses pejalan kaki. Area publik memiliki zona parkir, yaitu sebanyak 84 buah motor dan 52 mobil untuk tamu serta 3 parkir bus. Area parkir privat yang tersedia untuk parkir pelaku utama berjumlah 540 motor untuk mahasiswa, 50 mobil untuk mahasiswa, 84 motor untuk staf pengajar, 30 mobil untuk staf pengajar, 100 motor untuk staf administrasi dan servis dan 30 mobil untuk staf administrasi.

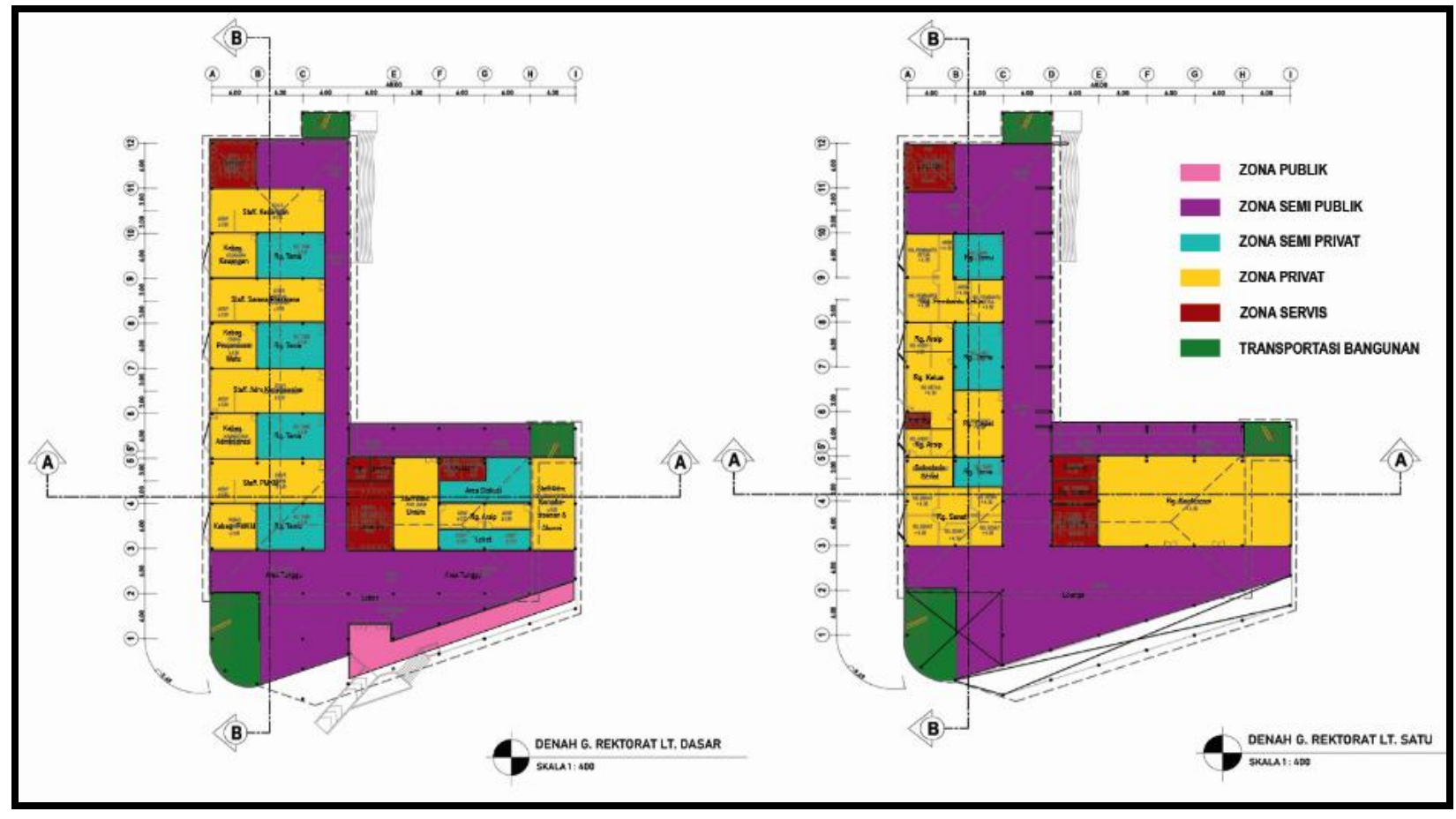

Gambar 7. Denah Gedung Rektorat Sumber: Penulis, 2020

Denah Gedung Rektorat Sekolah Tinggi Desain Komunikasi Visual di Kota Pontianak disajikan pada Gambar 7. Gedung ini merupakan jantung dari Sekolah Tinggi Desain Komunikasi Visual di Kota Pontianak yang berfungsi sebagai pusat administrasi dan informasi pendidikan tinggi. Gedung Rektorat terdiri dari 2 lantai dengan lantai dasar berfungsi sebagai pelayanan umum terkait kegiatan administrasi perguruan tinggi dan area privat untuk staf tata usaha, administrasi umum dan ketua staf serta lantai satu yang merupakan zona pimpinan dari Sekolah Tinggi Sekolah Tinggi Desain Komunikasi Visual berupa ruang ketua, ruang pembantu ketua, ruang senat serta sekretaris senat. Pada lantai ini juga terdapat area rapat maupun ruang konferensi.

Pada Gambar 8. disajikan denah Gedung Auditoirium. Gedung ini berfungsi untuk kegiatan kunjungan dan acara besar yang terdiri dari 2 lantai yang dapat menampung kapasitas 870 orang. Fasilitas lantai dasar berupa aula dan ruang pelengkapnya seperti ruang rias pria dan wanita, ruang kontrol, gudang, dan toilet. Adapun fasilitas lantai satu berupa tribun dan toilet. 


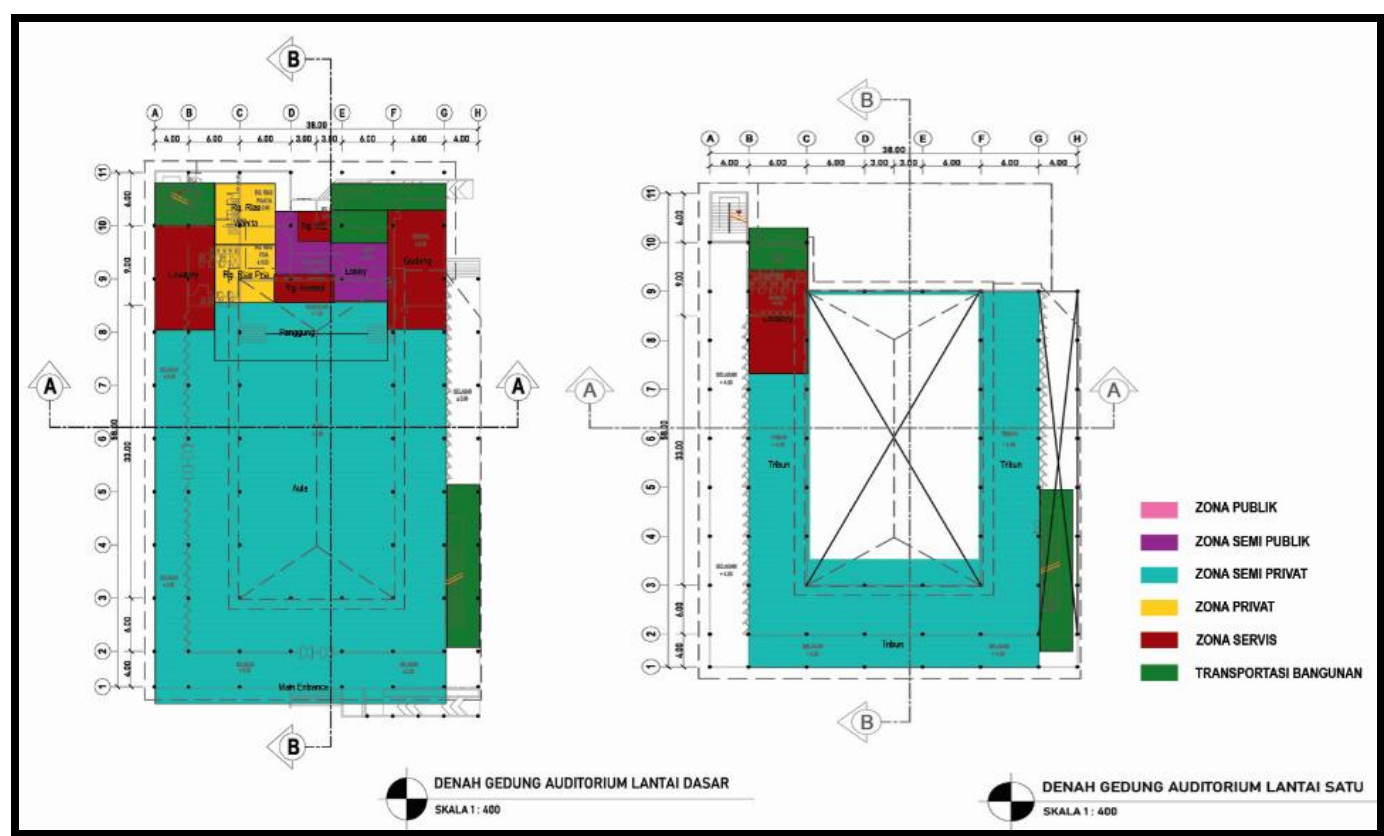

Gambar 8. Denah Gedung Auditorium

Sumber: Penulis, 2020

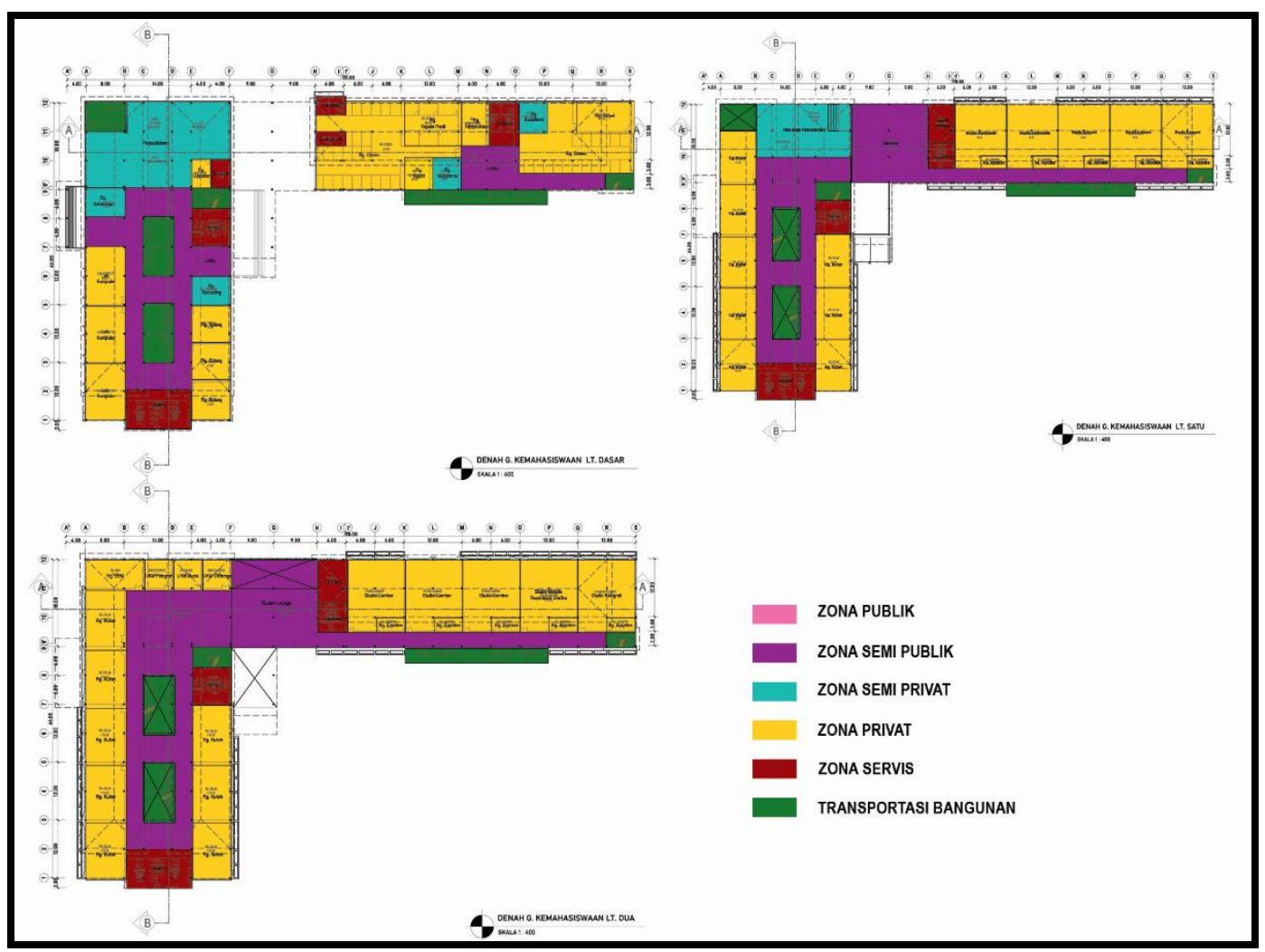

Gambar 9. Denah Gedung Kemahasiswaan

Sumber: Penulis, 2020

Gambar 9. menyajikan denah Gedung Kemahasiswaan. Gedung Kemahasiswaan terbagi menjadi 2 segmen utama, yaitu area kuliah teori dan kuliah praktik yang dihubungkan dengan area publik berupa cafeteria dan student lounge. Gedung ini terdiri dari 3 lantai dengan lantai dasar memiliki fasilitas untuk kegiatan administrasi serta diskusi bagi mahasiswa dan dosen seperti area 
ruang administrasi prodi, ruang sidang, ruang asistensi dan ruangan bimbingan konseling. Lantai satu dan lantai dua berfokus pada ruang kuliah teori, ruang kuliah praktik (studio), serta ruang untuk kegiatan kemahasiswaan.

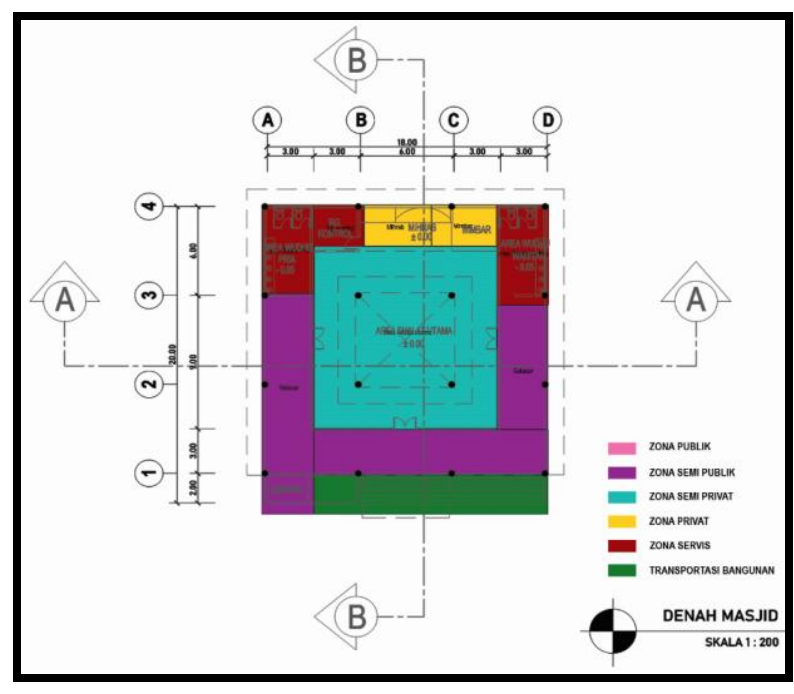

Gambar 10. Denah Masjid

Sumber: Penulis, 2020

Adapun massa bangunan yang terakhir yaitu Masjid yang merupakan bangunan penunjang sarana ibadah dalam kawasan. Masjid memiliki 3 akses masuk, dimana akses masuk utama mengarah langsung ke area mihrab dan mimbar sedangkan 2 akses lainnya berada pada sisi kiri dan kanan gedung yang menghubungkan antara area shalat dengan area wudhu. Sisi kanan merupakan area wudhu dan akses masuk bagi wanita dan sisi kiri merupakan area wudhu dan akses masuk pria. Denah gedung masjid disajikan pada Gambar 10.

Sekolah Tinggi Desain Komunikasi Visual di Kota Pontianak merupakan kawasan pendidikan tinggi terdiri dari empat massa. Empat massa tersebut saling memiliki kesinambungan dengan konsep playful and fun dengan penggunaan warna cerah pada fasad dan lansekapnya.

Suasana eksterior Sekolah Tinggi Desain Komunikasi Visual di Kota Pontianak memiliki kesatuan warna yang didominasi dengan warna putih dengan aksen-aksen cerah dan menonjol untuk menunjukkan entrance masuk ke dalam masing-masing massa bangunan. Gedung Rektorat dan Gedung Auditorium menciptakan unsur simetri pada fasad, hal ini dikarenakan dua massa ini merupakan ikon utama ketika masuk ke dalam kawasan. Pada kedua massa ini juga diberikan sun shading berupa permainan bentuk belah ketupat terbuat dari panel aluminium dan wiremesh dengan tujuan melindungi massa dari panas matahari sore. Adapun bentuk Gedung Kemahasiswaan memiliki bentuk yang lebih panjang daripada gedung lain karena fokus utama pada gedung ini untuk memenuhi kebutuhan ruang serta menciptakan pencahayaan dan penghawaan alami yang lebih banyak. Secara keseluruhan, massa bangunan memiliki kesamaan baik dari segi warna maupun material. Penggunaan warna yang cerah di dalam kawasan ini merefleksikan dari unsur kreatif dan imajinatif dengan material yang banyak digunakan berbahan aluminium sebagai unsur estetika dan tahan terhadap perubahan cuaca. 


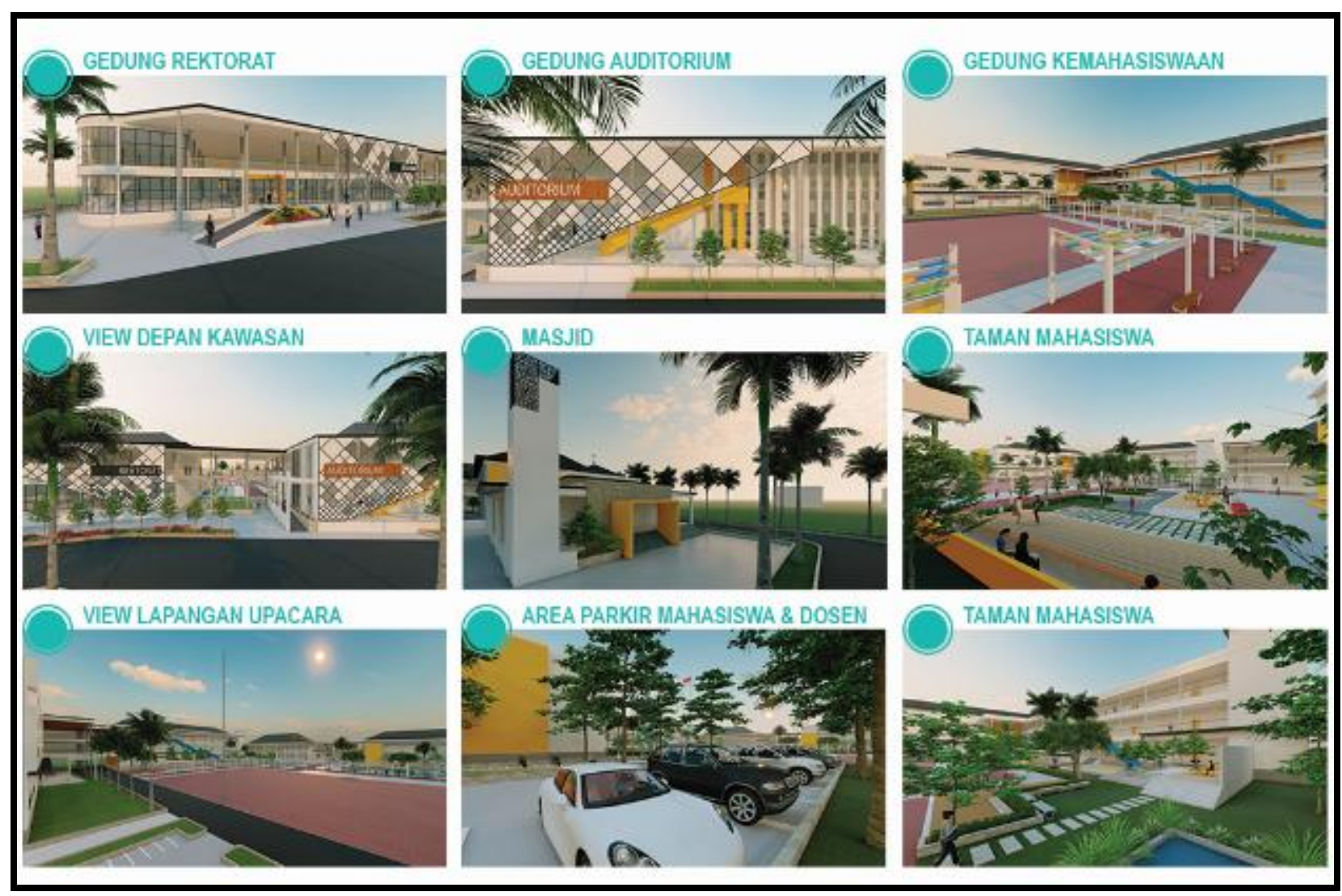

Gambar 11. Suasana eksterior Sekolah Tinggi Desain Komunikasi Visual di Kota Pontianak Sumber: Penulis, 2020

Suasana interior Sekolah Tinggi Desain Komunikasi Visual di Kota Pontianak juga didominasi dengan warna putih untuk menciptakan kesan ruang yang luas dengan penggunaan perabot dan aksen ruangan dengan warna-warna cerah untuk memberikan kesan ruang rekreatif dan imajinatif sesuai dengan konsep perancangan.

Suasana pada ruang kuliah (teori) didominasi dengan pewarnaan interior menggunakan palet warna putih di dinding dan lantai sesuai dengan warna pada dinding eksterior gedung kelas. Penggunaan perabot dengan warna cerah agar menimbulkan kesan ceria dan semangat dalam hal belajar.

Selain ruang kuliah (teori) sebagai ruang belajar, mahasiswa Sekolah Tinggi Desain Komunikasi Visual di Kota Pontianak juga membutuhkan ruang praktik untuk setiap jurusan. Sekolah Tinggi Desain Komunikasi Visual di Kota Pontianak menyediakan studio untuk mengembangkan kemampuan mahasiswa. Nuansa dari ruang studio menciptakan kesan yang minimalis dan hangat. Kesamaan aksen ruangan yaitu dari penggunaan material penutup lantai berupa lantai vinyl motif kayu dan perabot berwarna putih. Suasana interior Sekolah Tinggi Desain Komunikasi Visual di Kota Pontianak disajikan pada Gambar 12. 


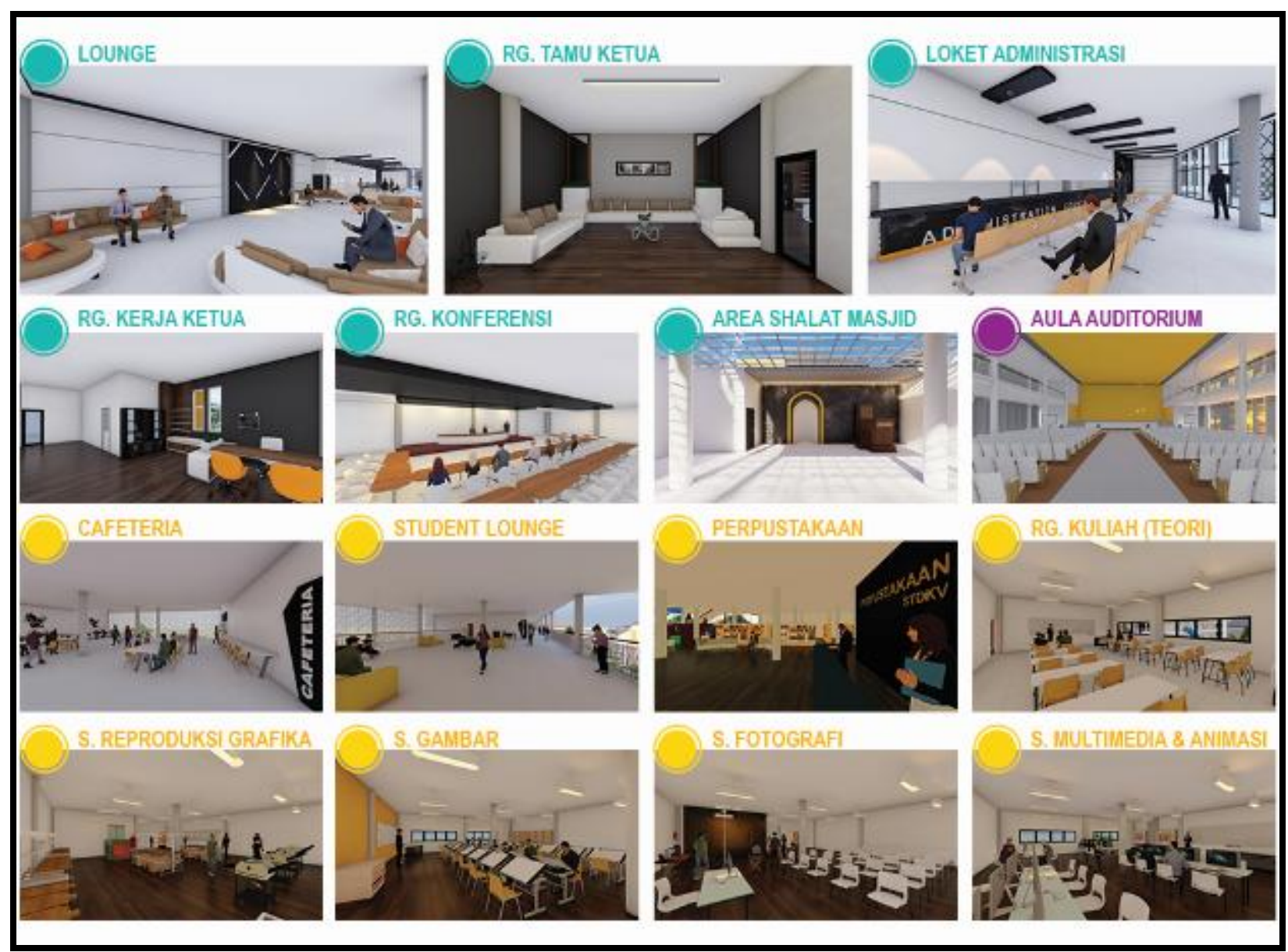

Gambar 12. Suasana interior Sekolah Tinggi Desain Komunikasi Visual di Kota Pontianak Sumber: Penulis, 2020

\section{Kesimpulan}

Sekolah Tinggi Desain Komunikasi Visual di Kota Pontianak merupakan Lembaga Pendidikan Tinggi yang menyelenggarakan pendidikan vokasi dan akademik di bidang desain dengan mempelajari segala sesuatu yang berkaitan dengan media komunikasi (terutama media komunikasi visual). Sekolah Tinggi ini menyediakan fasilitas untuk aktivitas belajar mengajar teori dan praktik, administrasi, penunjang dan komersial. Konsep perancangan Sekolah Tinggi ini menerapkan konsep playful and fun yang berfokus pada penggunaan warna cerah serta material bangunan dan material lanskap yang menyesuaikan kondisi iklim Kota Pontianak dengan bentuk dasar bangunan yaitu berbentuk persegi karena lebih menekankan pada aspek fungsional sehingga penyusunan ruang lebih efektif dan efisien. Tujuan yang ingin dicapai dari Perencanaan dan Perancangan Sekolah Tinggi Desain Komunikasi Visual di Kota Pontianak adalah menghasilkan rancangan Sekolah Tinggi Desain Komunikasi Visual di Kota Pontianak dengan sarana dan prasarana yang tepat dan sesuai dengan kebutuhan perancangan. Sehingga dalam program pendidikannya, sekolah tinggi ini dapat menunjang pengembangan keterampilan dan kreativitas penggunanya, diharapkan juga akan dapat menghasilkan tenaga kerja professional.

\section{Ucapan Terima Kasih}

Ucapan syukur kepada Tuhan Yang Maha Esa dan ucapan terimakasih kepada orang tua, kepada Bapak Ir. Rudiyono, M.T. selaku dosen pembimbing utama, Bapak Dr. Uray Fery Andi, S.T., M.T. selaku dosen pembimbing pendamping; Bapak Hamdil Khaliesh, S.T., M.T., selaku dosen 
penguji utama; Bapak Syaiful Muazir, S.T., M.T., Ph.D., selaku dosen penguji pendamping yang telah membimbing, memberikan kritik dan saran untuk penulis serta ucapan terimakasih kepada seluruh dosen dan staf Program Studi Arsitektur Universitas Tanjungpura yang telah memberikan ilmu yang bermanfaat selama ini.

\section{Daftar Acuan}

Ardjaka, S. (2004). Metodologi Desain, Bagian 1: Sebuah Pendekatan Penelitian. Malang: Universitas Negeri Malang Badan Ekonomi Kreatif. (2016, December 15). Data Statistik dan Hasil Survei Ekonomi Kreatif. Retrieved from https://bisma.bekraf.go.id/info-kreatif

Badan Perencanaan Pembangunan Daerah Kota Pontianak. (2013). Rencana Tata Ruang Wilayah (RTRW) Kota Pontianak Tahun 2013-2033. Pontianak: Badan Perencanaan Pembangunan Daerah Kota Pontianak

Badan Pusat Statistik Kota Pontianak. (2017, September 20). Kondisi Perekonomian Kota Pontianak. Retrieved from https://diskominfo.pontianakkota.go.id/?p=8549

Kementerian Ketenagakerjaan Republik Indonesia. (2016). Keputusan Menteri Ketenagakerjaan Nomor 301 Tahun 2016 Tentang Penetapan Standar Kompetensi Kerja Nasional Indonesia Kategori Aktivitas Profesional, Ilmiah dan Teknis Golongan Pokok Aktivitas Profesional, Ilmiah dan Teknis Lainnya Bidang Desain Grafis dan Desain Komunikasi Visual. Jakarta: Kementerian Ketenagakerjaan Republik Indonesia

Kementerian Riset, Teknologi, dan Pendidikan Tinggi Republik Indonesia. (2015). Peraturan Menteri Riset, Teknologi, dan Pendidikan Tinggi Nomor 44 Tahun 2015 Tentang Standar Nasional Pendidikan Tinggi. Jakarta: Kementerian Riset, Teknologi, dan Pendidikan Tinggi Republik Indonesia

Munaf, T. (2016, December 15). Keberadaan Desain Komunikasi Visual/Grafis dan Desain Produk. Retrieved from https://bisma.bekraf.go.id/

Nuraini, C., Sudrajat, I. (2010). Metode Perancangan Arsitektur. Bandung: Karya Putra Darwati

Persada, M.E.P. (2015). Pusat Pendidikan Desain Komunikasi Visual Modern di Yogyakarta. Yogyakarta: Universitas Atma Jaya

Saputra, E. (2010). Pusat Apreasiasi Desain Grafis di Yogyakarta. Yogyakarta: Universitas Atma Jaya

Sekretariat Negara Republik Indonesia. (2012). Undang-Undang Nomor 12 Tahun 2012 Tentang Pendidikan Tinggi Sekolah Tinggi. Bab VI. Perguruan Tinggi Pasal 59. Jakarta: Sekretariat Negara Republik Indonesia 